\title{
Phytochemical and Molecular Dynamic Analysis of Novel Biomolecule Lancifotarene Extracted From Conocarpus Lancifolius as Cytotoxic, Antiurease and Antidiabetic Agent
}

Research Article

Keywords:

Posted Date: April 2nd, 2021

DOI: https://doi.org/10.21203/rs.3.rs-182619/v2

License: (1) This work is licensed under a Creative Commons Attribution 4.0 International License.

Read Full License 


\section{Abstract}

The authors have requested that this preprint be withdrawn due to erroneous posting.

\section{Full Text}

The authors have withdrawn this preprint from Research Square. 